\title{
IMPLEMENTATION OF 5S TOOLS AS A STARTING POINT IN BUSINESS PROCESS REENGINEERING
}

\author{
UDC: 005.591 .4 \\ Original Scientific Paper \\ Miloš VORKAPIĆ ${ }^{1}$, Dragan ĆOĆKALO ${ }^{2}$, Dejan ĐORĐEVIĆ ${ }^{2}$, Cariša BEŠIĆ ${ }^{3}$ \\ ${ }^{1}$ University of Belgrade, Institute of Chemistry, Technology and Metallurgy - Centre for Microelectronic \\ Technology and Mono-crystals, 11000 Belgrade, Njegoševa 12, Republic of Serbia \\ E-mail: worcky@ nanosys.ihtm.bg.ac.rs \\ ${ }^{2}$ University of Novi Sad, Technical Faculty "Mihajlo Pupin” Zrenjanin, 23000 Zrenjanin, Đure Đakovića bb, \\ Republic of Serbia \\ ${ }^{3}$ University of Kragujevac, Faculty of Technical Science, 32000 Čačak, 65 Svetog Save, Republic of Serbia
}

Paper received: 10.04.2017.; Paper accepted: 22.05.2017.

\begin{abstract}
The paper deals with the analysis of elements which represent a starting point in implementation of a business process reengineering. We have used Lean tools through the analysis of $5 \mathrm{~S}$ model in our research. On the example of finalization of the finished transmitter in IHMT-CMT production, $5 \mathrm{~S}$ tools were implemented with a focus on Quality elements although the theory shows that BPR and TQM are two opposite activities in an enterprise. We wanted to distinguish the significance of employees' self-discipline which helps the process of product finalization to develop in time and without waste and losses. In addition, the employees keep their work place clean, tidy and functional.
\end{abstract}

Keywords: Reengineering, TQM, Lean concept, 5S, Production improvement.

\section{INTRODUCTION}

The concept of reengineering is firstly interested in WHAT an enterprise has to do and then in HOW it will do it. It is focused on "what should be", so it has a strategic role.

The main goal of this paper is to point at the significance of the transfer from traditional way of doing business to the modern one (innovative) by means of reengineering. Using TQM or Kaizen is becoming more and more significant. The essence of reengineering is in connecting all these elements in an integrated process which is nowadays much more intellectual than mechanical.

\section{Notion of Reengineering}

Reengineering does not represent a modification of the current business but it starts from the beginning and searches for better ways of business performance, different from the previous one. The current processes are mainly old-fashioned and inappropriate because they are not able to fulfill the requirements of both enterprises and buyers any more.

It is a brand new form and structure of the business process, a new quality. Reengineering represents a complex operation in which everything, except the final objective, is changing. Apart from increasing the productivity, the objectives include healthy work environment, knowledge and collaboration of employees at all levels, problem identification, acceptance of constructive suggestions and critics of employees, team work and discipline.

Reengineering was started by the idea that all changes in the environment should be overcome (Benins \& Mische, 1995). These changes are caused by implementing new science and technology, fast aging of organizations and their business processes.

According to Hammer (1990), the enterprises can achieve radical improvement of performances if they use reengineering of business processes, in other words, if they manage to abandon old rules 
of business and organization. Reengineering can be introduced as a difficult and risky process but it is still the best option for the enterprises which want to take the new strategic path, although dangerous by itself (Dixon, Arnold, Heineke, Kim, \& Mulligan, 1994; Adeiemi \& Aianda, 2008). However, according to Hammer (1995), reengineering brings changes, new ideas, attitudes, new technologies and work organization.

According to Verespej's analysis (Verespej, 1995), on the example of American and European enterprises, the application of reengineering is justified if enterprises: 1 . have problems, 2 . still do not have problems but they can predict them; and 3. do their business well but they want to make progress. On the other hand, Hall, Rosenthal and Wade (1993) determined that $50-70 \%$ of reengineering business processes did not give the expected results. In the same time, they found out that there was some progress in certain segments: $20 \%$ of cost reduction, $50 \%$ of time process reduction and $25 \%$ of quality rise.

According to Smith (1982), there are two types of approach in reengineering:

- Gradual - it is characterized by a small risk, easy management, less turbulence in short time intervals and

- Radical - based on the idea that when permanent changes or individual corrections do not give results, the only way to change the status is to be exposed to radical changes and the implementation of fresh, new solutions.

Radical changes can be achieved by changing organizational performances, such as: price, production time, service, quality, application of different tools and techniques in the realization of certain business activities, (Johansson, 1993).

Reengineering is a process that contributes to transformation in enterprise's business but the main reason for failure is caused by a tendency to change all processes at once and in the same time, (Davenport \& Stoddard, 1994).

\section{The Phases of Reengineering}

According to Harrington (1998) the reengineering process is developed in three phases (Figure 1):

1. Project plan (PLAN). The need for reengineering should be determined and the process that should be designed again is selected. The first phase assumes clear development of the vision related to the future state of the target process. Clear vision and objectives are necessary for success of reengineering;

2. Understanding the process (ANALYSIS). In the second phase the analysis of organizational structure is performed, in other words, the comparison with other enterprises is carried out. Then, a certain modeling process important for reengineering is made. Business process can be understood better on the basis of the model;

3. Forming new processes (PRODUCTION). In the third phase it is necessary to make innovations in business processes. All possible solutions originated from this phase should be valued;

4. Transfer to new solutions (DEVELOPMENT). When a new solution is ready it is necessary to plan and improve the process of transformation of the old model into the new one. After that, it is necessary to monitor business processes established by reengineering.

5. Process control (CONTROL). Process control assumes quality improvement and reduction of errors in production process. Detailed process can reveal all advantages and disadvantages of the process, or guidelines for further progress.

Doomun and Jungum (2008) presented a very flexible approach to modeling, simulation and reengineering of business processes. Modeling starts with precise definition of objectives and model disadvantages and data analysis follows. By stimulation of business processes, testing and analysis of different scenarios are enabled to make possible understanding and estimation of their influence on the system as a whole, before going to the plan of reengineering application. The presented model is good for process improvement or reengineering, primarily due to its flexible configuration which can be adjusted to gradual or radical changes.

\section{Factors of Business Process Reengineering}

According to Earl, Sampler and Short (1995), Grover, Jeong, Kettinger and Teng (1995) and AlMashari and Zairi (1999) among the main factors of Business process reengineering (BPR - Business process reengineering) there are: culture (new beginning, change in the process of thinking), processes (an attempt to do business differently and a fundamental change in problem solution), structure (dynamic and creative approach to 
business, reorganization and redesign of business processes) and technology (orientation to fundamental business processes based on new technology).

\begin{tabular}{|c|c|c|c|c|}
\hline Plan & Analysis & Production & Development & Control \\
\hline $\begin{array}{l}\text {-Vision } \\
\text {-Objectives } \\
\text { - Business policy } \\
\text { - Resources } \\
\text { - Security of } \\
\text { monetary means } \\
\text {-Quality }\end{array}$ & $\begin{array}{l}\text { - Process state } \\
\text { monitoring } \\
\text { - Finding critical } \\
\text { points of the } \\
\text { process } \\
\text { - Financial } \\
\text { harmonization }\end{array}$ & $\begin{array}{l}\text { - New process } \\
\text { modeling } \\
\text { - Process simulation } \\
\text { - Introducing } \\
\text { innovations }\end{array}$ & $\begin{array}{l}\text { - Transitional regime } \\
\text { of process and sub- } \\
\text { process work } \\
\text { - Application of } \\
\text { advanced } \\
\text { technological } \\
\text { solutions } \\
\text { - Education of } \\
\text { employees }\end{array}$ & $\begin{array}{l}\text { - Permanent } \\
\text { analysis, } \\
\text { examination and } \\
\text { control of } \\
\text { production } \\
\text { process }\end{array}$ \\
\hline
\end{tabular}

Figure 1: Phases of Reengineering

\section{The Objective of Reengineering}

The objective of reengineering is related to satisfying customers' needs and in this particular case the attention should be paid on the following:

- It is necessary to work fast. Reengineering will not be successful if the process is slow because it should be carried out until the resistance in the organization appears;

- Risk is unavoidable. There is no progress without risks. The unknown is always frustrating but the greatest risk comes from unchanged state;

- Imperfection must exist. Mistakes cannot be avoided whenever something new and unknown is done. Mistakes are necessary for learning; and

- Activities mustn't be stopped suddenly. A great number of enterprises stop reengineering process as soon as the results are visible. It is bad because the final objective is important and the process must not be stopped when the first problems appear.

\section{TQM AND BPR - SIMILARITIES AND DIFFERENCES}

TQM and BPR can be seen as two different alternatives for the enterprise which have both differences and some mutual characteristics. On one side, TQM considers the existing system useful but it should be improved, while on the other side, reengineering rejects any alterations and advocates for completely new, creative and modern approach.
TQM represents an approach for improving competitiveness, efficiency and flexibility. According to Oakland (1993) TQM is a type of planning, organizing and understanding of every activity in the enterprise and it depends on every employee at all levels. On the other hand, Kelada (1994) states that BPR represents a tool for TQM. The necessary element of TQM is permanent improvement which is developed gradually and represents the objective of BPR. Reengineering of the organization first includes the analysis of interested parties, customers and the needs of employees. Then, the comparison of these needs is performed at the business level and possible needs for changes are discovered, (Kelada, 1994).

According to Cole (1994), the similarities between TQM and BPR can be seen in: an orientation to processes, initiative for introduction of business improvement, increasing the satisfaction of both customers and employees, responsibility delegation, assigning authority as well as needs for education and training.

There are considerable differences between BPR and TQM methodology. Klein (1993), states that BPR is much more radical than TQM. Continual, small improvements are achieved by applying TQM while BPR offers obvious and sudden improvements. TQM requires inclusion of all employees while BPR demands team work. TQM demands smaller investments unlike BPR; TQM requires inclusion of all processes while BPR involves individual crisis processes. Finally, it is necessary to stress that TQM assumes voluntary 
M. Vorkapić Implementation of 5S tools as a starting point

et al. in business process reengineering

inclusion of employees and, BPR performs the process by strict order. Hence, Gadd and Okland (1996) found out that TQM and BPR can be seen as two separate and different approaches that may coexist in the same organization but should be used in different time for achieving various levels of performance improvements. In addition, McLay (2014) gives the essential differences between TQM and BPR (see Table 1).

Table 1: Differences between TQM and BPR

\begin{tabular}{|l|l|}
\hline \multicolumn{1}{|c|}{ TQM } & \multicolumn{1}{c|}{ BPR } \\
\hline $\begin{array}{l}\text { Improvement of the current } \\
\text { system }\end{array}$ & New beginning \\
\hline Continuous improvement & Drastic changes \\
\hline $\begin{array}{l}\text { Includes all organization } \\
\text { segments }\end{array}$ & $\begin{array}{l}\text { Oriented to individual } \\
\text { organization segments }\end{array}$ \\
\hline Stress on standardization & Stress on flexibility \\
\hline Static control & Information Technologies \\
\hline Smaller risks in applying & Big risks in applying \\
\hline Short preparation time & $\begin{array}{l}\text { Time for applying } \\
\text { medium to long }\end{array}$ \\
\hline
\end{tabular}

It can be concluded that BPR: improves organization structure; enables fast and drastic changes; increases quality and reduces costs; decreases the time of process performance; improves internal and external relations; eliminates unnecessary activities; makes pleasant work atmosphere and defines broad responsibility of employees.

Unfortunately, because of big costs at applying BPR and a high percentage of failure, it is recommended to enterprises which do not have great problems in their business to implement TQM system, (McAdam, 2003).

\section{LEAN AS A TOOL FOR BPR MODELING}

Lean concept (LC) represents both a production philosophy and business strategy. As a business strategy LC is based on customers' satisfaction with products or services. Lean eliminates all sources of waste during the production process (Karlsson \& Åhlström, 1996). Lean, because of its functionality, is applied to complete production process, in other words, to all organizational segments within the enterprise. The very application and implementation of LC in production process is carried out by plan, gradually (step by step). Lean improves the current production process and allows finishing and improvement.
Lean concept defines seven types of production waste (Bicheno \& Holweg, 2009):

1. Excessive production which means: making products that cannot be sold on the market, writing unnecessary documentation.

2. Transport, which assumes: unnecessary movement of materials (semi products) between operations or warehouses, inefficient transfer of information, unsuccessful communication caused by data losses or information incompatibility, waiting time for materials between two operations, idling, waiting for delivery.

3. Excessive processing defines: oversized machines, unnecessary or missing equipment, poor preparatory of final time, cleaning between operations, too many steps in processing caused by poor product design, etc.

4. Unnecessary supplies which imply at: excessive supplies are caused by an excessive production (there is "dead capital" in warehouses).

5. Useless movements point at inefficient and needless movements of employees due to bad arrangement of machines.

6. Insufficient use of employees' potentials is caused by inappropriate and inefficient use of their intellectual potential or due to lack of appropriate intellectual capital in the enterprise. Intellectual capital is related to knowledge, experiences, skills, proficiency and abilities of all those within the enterprise who tend to achieve better results and give more advanced services.

7. Reject/waste means inappropriate realization of a business process, waste of time and means for failure analysis and elimination of causes, insufficient training of employees or lack of standard procedure.

\section{S TOOLS}

Ho (1999) gave the model in which 5S tools and BPR are grouped on operation level management while TQM is positioned on strategic management level. General concept of $5 \mathrm{~S}$ tools is aimed at waste elimination, (Osada, 1993). It is relatively easy to put into practice and demands minimum additional resources. The purpose of $5 \mathrm{~S}$ is to reduce the number of stoppages and work time loss.

On the other hand, 5S can be represented as a system which makes possible the creation of necessary conditions for implementation of new technical solutions. The system is based on 
innovative ideas, optimization of work space and production process are performed as well. 5S system assumes systematic approach that involves team work, including participation of all employees. The focus is on total application of work organization and adaptation of work space.

5S tools are used on micro level, in other words, on the level of work space (Veža, Gjeldum, \& Celent, 2011). The implementation of these tools encourages employees to improve their work conditions and helps them in reducing: waste, unplanned stoppages and unnecessary inventory (Gapp, Fisher, \& Kobayashi, 2008). In relation to this, Chapman (2005) distinguishes the importance of $5 \mathrm{~S}$ tools for production system and management of production operations which decreases human efforts, space, capital, time, errors, but it can also become a starting platform for integrated management system (Bamber, Sharp, \& Hides, 2000; Vorkapić, Popović, Ćoćkalo, Đorđević, \& Minić, 2015).

$5 \mathrm{~S}$ is derived from the first letters of Japanese words: Seiri, Seiton, Seiso, Seiketsu and Shitskue.

1. Seiri (Sort - sorting) means eliminating unnecessary things at workplace. The objects which are completely useless are put at some other place (Peterson \& Smith, 2001). The role of sorting is elimination of waste, old machines and tools and broken ones as well (Harrington, 2000). In relation to this, sort has the following characteristics (Osada, 1993):

- Elimination of obstacles at workplace,

- Reduction of unnecessary things distribution,

- Prevention of unnecessary things accumulation,

- Elimination of parts and tools that are no longer in use,

- Taking away unnecessary material from workplace,

- Saving the workplace for necessary (green) and unnecessary (red) objects,

- Elimination of waste.

2. Seiton (Straighten - put everything in the right place). Seiton can be translated as "tidiness". It means that all objects are put in the right place, easily accessible, so the time for searching is eliminated. When everything is set in order, then quality and safety are secured. The focus is here on efficient warehousing and long-term activities (Peterson \& Smith, 2001). It implies consulting and training of employees and discipline at workplace. Set in order has the following characteristics:

- Enables an easy access to all necessary items,

- Prevents time loss for tidying the workplace,

3. Seiso (Shine - tidying). Seiso puts emphasis on tidying. On the other hand, tidying is a kind of inspection that determines unexpected conditions which could jeopardize quality or machine failure. In the same time, tidying eliminates waste (Osada, 1993). Seiso has the following characteristics:

- Secures clean workplace,

- Tidying is a form of inspection of workplace, equipment and machines.

4. Seiketsu (Standardize). The previous three elements represent a routine while the standardize puts emphasis on visual management of afore mentioned S elements. In other words, it is important to achieve and keep standardized conditions that will enable individuals to act fast at their workplaces (Osada, 1993). Standardization is about procedures and activities necessary for keeping workplace clean and tidy, tools and raw materials accessible to workers and keeping away all objects that are unnecessary. Standardize has the following characteristics (Michalska \& Szewieczek, 2007):

- Standardize only those items that proved to have the best usage,

- Keeping the highest standards in workplace organization at any time,

- Keeping everything clean and tidy according to standard,

- Put everything in the right place,

- Every process must be standardized.

5. Shitsuke (Sustain) Sustain indicates the possibility to make workplace with good habits and discipline. It has the following characteristics:

- Enables permanent training and discipline at workplace,

- Promotes work habits based on defined rules and procedures,

- Carrying out regular revisions at workplace,

- Makes good ambience and healthy workplace,

- Enables team work. 
M. Vorkapić Implementation of 5S tools as a starting point

et al. in business process reengineering

\section{AN EXAMPLE OF 5S TOOLS IMPLEMENTATION IN THE ASSEMBLY OF PRESSURE AND TEMPERATURE TRANSMITTER}

As an example of realization and application of $5 \mathrm{~S}$ tools this paper will analyze the process of finishing and assembly of temperature and pressure transmitter. On the grounds of this example we wanted to check if these tools fulfilled input conditions before BPR implementation, viewed from the aspect of complete waste elimination that would not be analyzed in reengineering. Although the theory confirms that TQM and BPR are essentially different, we want to show on our example that there is a close connection in implementing crucial procedures of quality system.

Figure 2 presents a detail of a workplace with additional material, equipment and machines. The finished item brought from a workshop is first washed and dried and then after visual control it is polished/cut/drilled. Figure 2 presents an inappropriate workplace in the process of transmitter finalization that should be arranged and sorted according to 5S methodology. Figure 3 presents the effects of $5 \mathrm{~S}$ tools implementation.
Table 2 shows methodoligical approach of these tools application. All elements are analyzed here according to the following criteria: 1) significance level - (the existing level and what activities have been taken?), 2) Note (Why is it important?) and 3) Problem solution (How to end problems and how to achieve the wished results?)

In the next phase of problem solution, in Figure 4, it is presented work-surface used for assembling mechanical and electronic joints in one entity, a transmitter. It can be seen that there are elements that do not belong to this process and self-control and self-discipline at workplace do not exist. Red zones are examples of bad practice and the presence of large amounts of waste from the past reserves and from piling unnecessary tools and equipment. Green zones with red marks show that the existing elements should be at the same place but they must be rearranged.

Hence, the principle of $5 \mathrm{~S}$ tools application is the same, although we are going to consider only the significance level, see Table 3 .
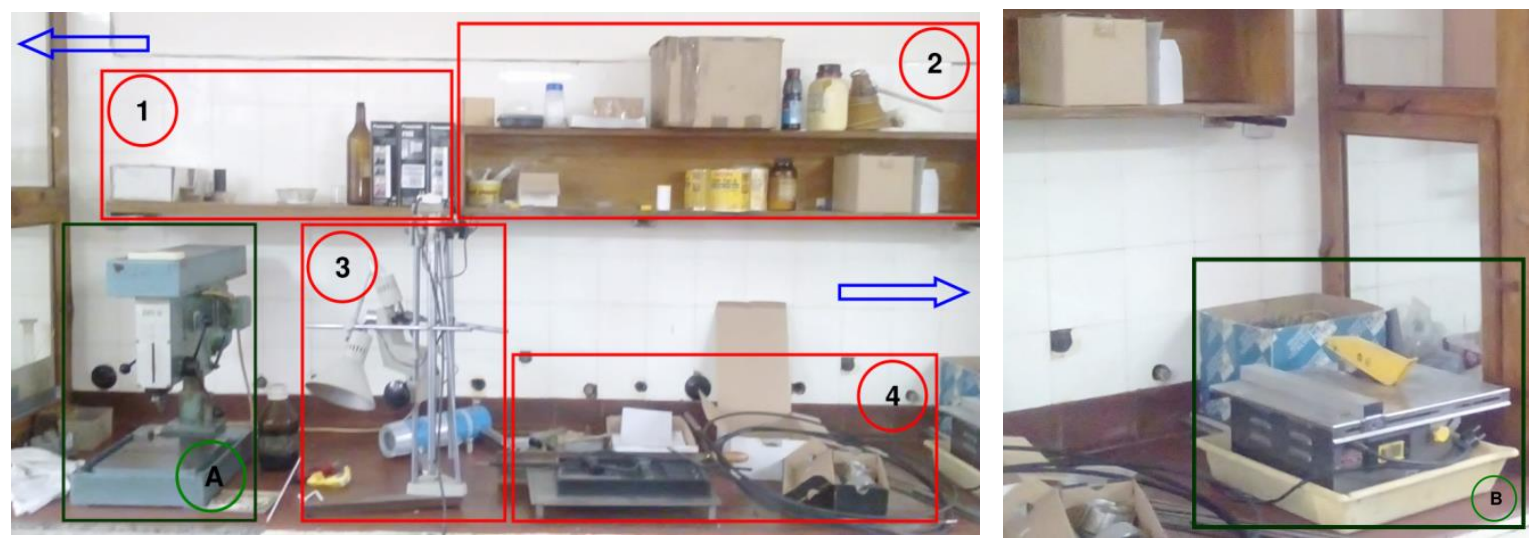

Figure 2: A detail of inappropriate workplace for reception and control of finished items

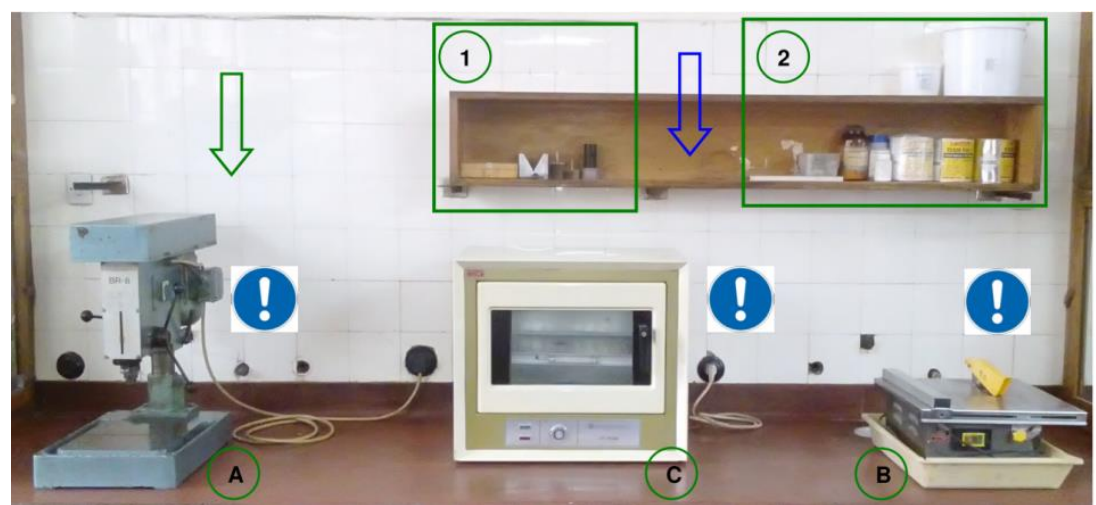

Figure 3: A detail of a sorted workplace by 5S tools implementation 


\begin{tabular}{ll}
$\begin{array}{l}\text { M. Vorkapić } \\
\text { et al. }\end{array}$ & Implementation of $5 \mathrm{~S}$ tools as a starting point \\
\hline
\end{tabular}

Table 2: Application of 5 S tools at reception of the finished elements from the workshop

\begin{tabular}{|c|c|c|c|}
\hline Element & Significance level & Note & Problem solution \\
\hline ڤ̆ & $\begin{array}{l}\text { Based on the facts, all unnecessary elements were } \\
\text { taken away. In Figure } 2 \text { they are marked by numbers } \\
1,2,3,4 \text { and framed in red color. Unnecessary } \\
\text { objects were taken away because they are not needed } \\
\text { in future operations. } \\
\text { Red zone: } \\
\text { 1. All elements from the shelf were taken away and } \\
\text { the shelf itself for safety reasons while handling the } \\
\text { pole drill. } \\
\text { 2. The shelf is functional. Only necessary elements } \\
\text { were left while the surplus was taken away. } \\
\text { 3. Pole microscope was taken away because the } \\
\text { control of elements is carried out in machine } \\
\text { workshop (tolerance, dimensions, testing of joints, } \\
\text { sealing). } \\
\text { 4. Various unnecessary objects, auxiliary utensils, } \\
\text { package elements are taken away. } \\
\text { Green zone: } \\
\text { A. The pole drill stays in the shown place. } \\
\text { B. The machine for ceramics cutting stays in the } \\
\text { shown place. }\end{array}$ & $\begin{array}{l}\text { By doing this, the most } \\
\text { efficient management } \\
\text { and usage of space, } \\
\text { energy, time and money } \\
\text { are provided. } \\
\text { Problems and } \\
\text { unpleasant situations in } \\
\text { the work process are } \\
\text { decreased. } \\
\text { Communication among } \\
\text { workers becomes better } \\
\text { and productivity and } \\
\text { quality are improved. }\end{array}$ & $\begin{array}{l}\text { Unnecessary objects are taken or } \\
\text { thrown away. Loss of time earlier } \\
\text { spent on searching for parts or } \\
\text { equipment is reduced. }\end{array}$ \\
\hline 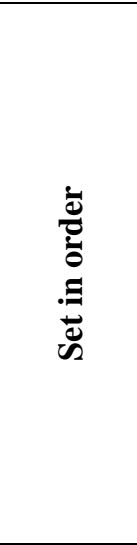 & $\begin{array}{l}\text { Based on the example, the objects, machines and } \\
\text { tools are arranged correctly in order to be used. After } \\
\text { usage, the elements can be easily returned to its place. } \\
\text { Green zone: } \\
\text { 1. The tools and auxiliary utensils for pole drill are } \\
\text { separated. } \\
\text { 2. Various elements important for assembly and joints } \\
\text { and sub-joints are sorted (glue, gel, silicone ointment, } \\
\text { polishing gel for welded joints) } \\
\text { A. Pole drill - the space is adequate and safe for } \\
\text { usage. } \\
\text { B. The machine for ceramics cutting - the space } \\
\text { behind is cleaned, so it is enabled for safe usage. } \\
\text { C. Drier - it was moved from other location and } \\
\text { therefore becomes more important. }\end{array}$ & $\begin{array}{l}\text { All types of waste are } \\
\text { eliminated: 1) previous } \\
\text { production, 2) surplus of } \\
\text { elements without utility } \\
\text { value, 3) the elements } \\
\text { which are not the part of } \\
\text { the production program. }\end{array}$ & $\begin{array}{l}\text { The procedure gives quality } \\
\text { discovery and searching for waste. } \\
\text { Waste displacement prevents the } \\
\text { loss of inventory, separation of } \\
\text { correct from incorrect products and } \\
\text { making better space for } \\
\text { manipulation at workplace. }\end{array}$ \\
\hline$\stackrel{\mathscr{\Xi}}{\stackrel{\Xi}{\Xi}}$ & $\begin{array}{l}\text { Application of the previous two elements shows that } \\
\text { the third one signifies the last element of physical } \\
\text { treatment of the problem. This element shows that the } \\
\text { arranged and tidied state should be kept clean on } \\
\text { daily basis with clearly put elements in their place. As } \\
\text { an illustration, in Figure } 3 \text {, the real solution of the } \\
\text { problem is given. }\end{array}$ & $\begin{array}{l}\text { Cleaned and arranged } \\
\text { workplace influences } \\
\text { employees to work } \\
\text { better. In the same } \\
\text { time, such workplace } \\
\text { enables employees to } \\
\text { use materials, tools and } \\
\text { other equipment in time } \\
\text { and without delay. } \\
\end{array}$ & $\begin{array}{l}\text { Better illumination of the workplace } \\
\text { should be provided so as dust, dirt, } \\
\text { water and oil leakage can be noticed } \\
\text { and eliminated. The same matters } \\
\text { for the access to machines and their } \\
\text { maintenance. }\end{array}$ \\
\hline 芯 & $\begin{array}{l}\text { Integrates all three elements in the whole. At this } \\
\text { level, the current elements are investigated according } \\
\text { to TQM and the procedures are standardized in } \\
\text { relation to exploitation and equipment maintenance. }\end{array}$ & $\begin{array}{l}\text { Quality elements, if } \\
\text { exist, are not rejected } \\
\text { but they are taken as the } \\
\text { starting point. }\end{array}$ & $\begin{array}{l}\text { The conditions in which there is no } \\
\text { going back to the old ones are made. } \\
\text { Working area is clean, equipped } \\
\text { with necessary materials, tools and } \\
\text { machines. Locations for storing } \\
\text { tools are eliminated because they } \\
\text { represent unorganized place in } \\
\text { which the time for searching is lost. }\end{array}$ \\
\hline 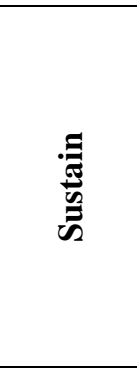 & $\begin{array}{l}\text { Based on the Figure } 2 \text { (old state) and Figure } 3 \text { (new } \\
\text { state), it is necessary to make the employees keep } \\
\text { their workplace tidy and according to the defined } \\
\text { procedures realize the given tasks. In the same time, } \\
\text { self-discipline is important on this level in order to } \\
\text { avoid injuries, damages and possible stagnation at } \\
\text { workplace. }\end{array}$ & $\begin{array}{l}\text { Workplace should be } \\
\text { kept clean and tidy. } \\
\text { Respect and self-control } \\
\text { at workplace of defined } \\
\text { procedures are sufficient } \\
\text { parameters which do not } \\
\text { let the process go back } \\
\text { to bad state. }\end{array}$ & $\begin{array}{l}\text { By establishing discipline at } \\
\text { workplace piling unnecessry objects } \\
\text { is prevented, such as tools, } \\
\text { equipment. They are putting back to } \\
\text { exactly defined places, work-surfice } \\
\text { are cleaned after usage, machines } \\
\text { are visualy monitored and after } \\
\text { work they are cleaned, cooled and } \\
\text { oiled. The used tools are, if dirty, } \\
\text { cleaned before putting in place. }\end{array}$ \\
\hline
\end{tabular}



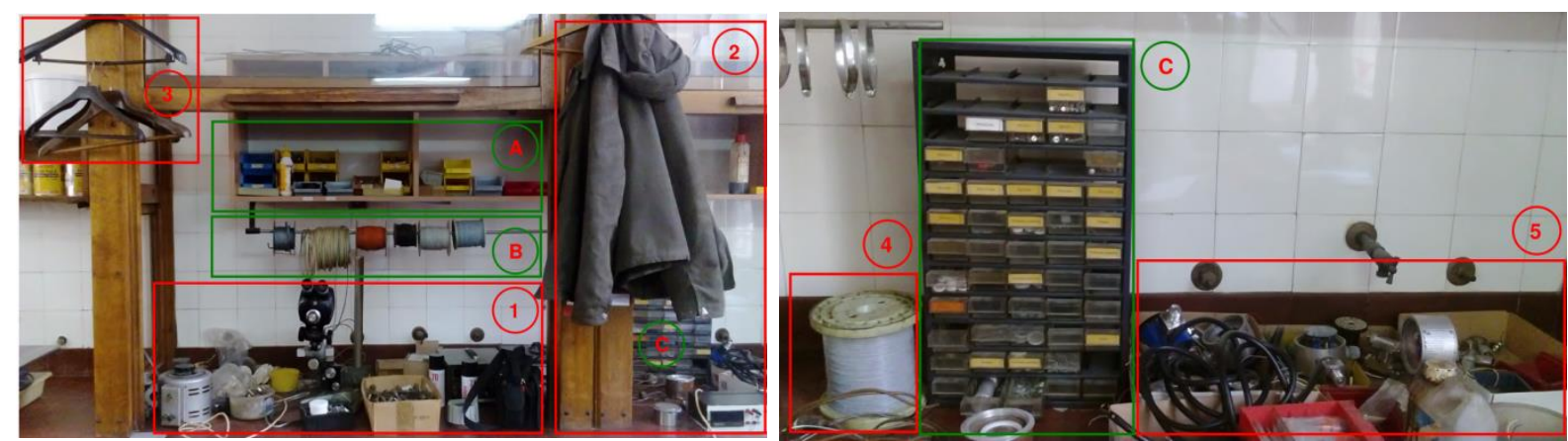

Figure 4: Presentation of inadequate work-surface for assembling mechanical and electronic joints

Table 3: Application of 5S tools in assembling the finished transmitter

\begin{tabular}{|c|c|}
\hline Element & Significance level \\
\hline Sort & $\begin{array}{l}\text { In Figure } 4 \text { all unnecessary elements and details are marked by ordinal numbers } 1,2,3,4,5 \text { and framed in } \\
\text { red color. Unnecessary elements are eliminated because most of them are not needed in the following } \\
\text { production operations either due to technological changes or the changes in production programs (some } \\
\text { products are technologically out of date and are not produced any more). } \\
\text { Red zone: } \\
\text { 1and 5. All elements were taken away from the work- surface, precisely, transmitters that were being } \\
\text { serviced out of warranty period as well as new transmitters. } \\
\text { 2. and 3. Personal possessions of the employee and additional unnecessary things were eliminated; this can } \\
\text { also be included in waste elimination. This issue is related to disrespect and lack of organizational culture } \\
\text { application. } \\
\text { 4. Wire coil is an important element in transmitter finalization and it must be put in its place } 4 \text {. Different } \\
\text { unnecessary objects, auxiliary materials and damaged elements were eliminated, too. } \\
\text { Green zone: } \\
\text { A. The space with the elements for joining mechanical and electrical parts exists and stays in its place. } \\
\text { B. The space for cable storage exists and stays in its place. }\end{array}$ \\
\hline Set in order & $\begin{array}{l}\text { On the grounds of the Figure 5, the following conclusion can be made: } \\
\text { Green zone: } \\
\text { A. All mechanical, winding elements and wire coils used in product finalization are sorted. } \\
\text { B. Wire coils for assembling and joints and sub-joints connections are sorted. } \\
\text { C. All electrical elements with additional parts are sorted in a separate classer in order to be connected to a } \\
\text { mechanical part of the transmitter (resistors, printed plates, protective masks, integrated circuits). } \\
\text { D. All devices used in testing new transmitter after assembling are sorted. These instruments were not at } \\
\text { this place earlier. } \\
\text { (glue, gels, silicone ointment, polishing gel...) } \\
\text { E. Additional material (welding paste, spray for laminating printed plates, silicone gel, universal glue) and } \\
\text { accompanying documentation (borrowed from TQM) are sorted properly, and can be accessible. } \\
\text { Technological procedure including soldering, gluing or joining together is not disturbed in this way. }\end{array}$ \\
\hline Shine & $\begin{array}{l}\text { This state can be kept clean and tidy on daily basis. Measurement equipment, tools and similar are put in } \\
\text { their place, see Figure } 5 \text {. }\end{array}$ \\
\hline Standardize & $\begin{array}{l}\text { All three mentioned elements are integrated in the whole. At this level, the existing elements according to } \\
\text { TQM are considered and the procedures are standardized in relation to exploitation and equipment } \\
\text { maintenance. }\end{array}$ \\
\hline Sustain & $\begin{array}{l}\text { Based on Figure } 4 \text { (the old state) and the Figure } 5 \text { (the settled/arranged state), it is concluded that employees } \\
\text { should make a habit - to keep their workplace clean and tidy regularly and realize the set tasks according to } \\
\text { defined procedures. Self-discipline is extremely important at this level. }\end{array}$ \\
\hline
\end{tabular}

Figure 5 presents set in order workplace in which the final assembling of transmitter is carried out

Standardized workplace indicates that BPR must collaborate with TQM, in other words, certain procedures and documents have to be pulled through this model. In relation to this, on the grounds of the existing procedures performed on our example, it can be concluded that the procedure on measurement equipment and the procedure on reception, supply and warehousing are of high significance. Therefore, employees analyze all elements of enterprise's business through self-control of work activities.

In addition to this analysis, here are presented the documents essential for efficient performance of work tasks, among them the most important are: 
receipt and register of equipment usage (Table 4), work order and product catalog.
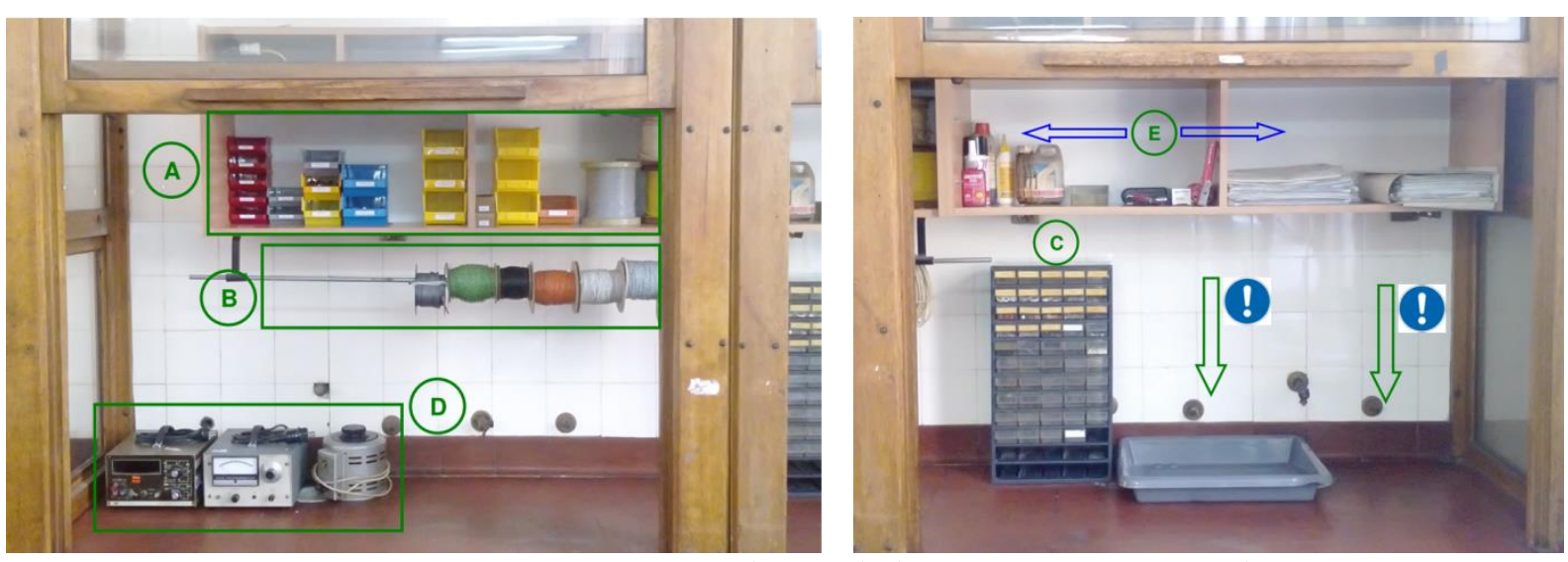

Figure 5: Presentation of set in order workplace in transmitter finalization

Table 4: Example of receipt and register of equipment usage in IHTM-CMT

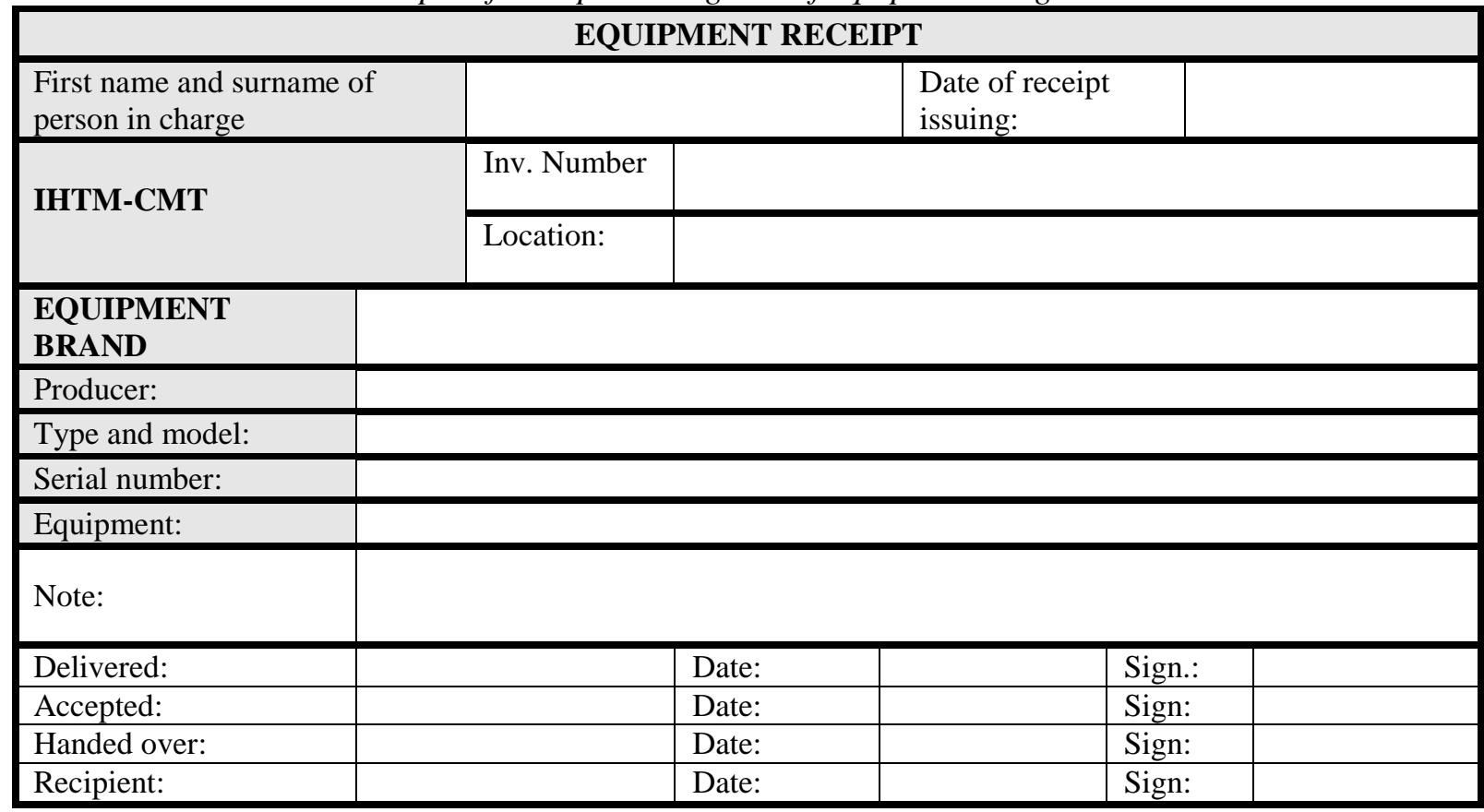

\section{REGISTER OF EOUIPMENT USAGE}

\begin{tabular}{|c|c|c|c|}
\hline Date & Done & Purchaser & Signiture \\
\hline & & & \\
\hline & & & \\
\hline & & & \\
\hline & & & \\
\hline & & & \\
\hline & & & \\
\hline
\end{tabular}

\section{CONCLUSION}

Traditional business activities cannot satisfy the basic objectives, such as price, quality, pace and other important indices of success. In the past it was sufficient to slightly improve the organization in order to be more efficient, but nowadays it is not the case. The implementation of reengineering represents a dramatic change in every enterprise, reconsideration of all existing postulates and the 
new beginning. Firstly, it requires special knowledge and energy of managers. Secondly, enterprises must have experts from specific fields: general jobs, marketing, design and production. Reengineering of business processes that is applied in crisis is necessary even when enterprises work well. Generally, all processes in enterprises represent reengineering object. Every process must be named appropriately: the process of ordering reception, the process of production preparation, production process, the process of product realization, distribution process. Reengineering is still a new venture and all who deal with it here are pioneers.

By application of $5 \mathrm{~S}$ tools we achieve great advantages in quality, equipment performances, productivity and safety in an enterprise. In relation to this, the advantages of $5 \mathrm{~S}$ tools are, first of all related to:

- Quality - permanent visual control is carried out so small mistakes can happen. The principle of self-control at workplace is present.

- Equipment performances - Routine cleaning of machines and tools is carried out for the sake of sudden and unplanned damage prevention.

- Productivity - Waste is reduced and the procedures defined for workplace are obeyed.

- Safety - Danger and risks at workplace are reduced. The procedure related to warehousing and organization of tools and equipment at workplace are obeyed.

In the enterprises in which everything is developed fast there is a pressure to see the results as fast as possible. According to Klarin, Cvijanović, Lazić and Spasojević-Brkić (2003), workplace supply with an appropriate work and its delivery have to be done fully and on time. Every workplace should be equipped by appropriate workers, machines, devices, tools, installations, materials, water, energy and means of protection.

Self-control at workplace must be integrated in the production process and it is carried out by a worker personally. If mistakes are noticed, the measures have to be taken promptly so the possible delay or stoppage of production is avoided. Self-control is an integral part od product realization and it is done by the workers in production: from control of parts and joints to final control of the finished product.

\section{ACKNOWLEDGEMENT}

This work was supported by the Serbian Ministry of Education and Science under Grant TR 35017 and TR 32008.

\section{REFERENCES}

Adeyemi, S., \& Ayanda, A. (2008). Impact Assessment of Business Process Reengineering on Organisational Performance. European Journal of Social Sciences, 7(1), 115-126.

Al-Mashari, M., \& Zairi, M. (1999). BPR implementation process: an analysis of key success and failure factors. Business process management journal, 5(1), 87-112.

Bamber, C. J., Sharp, J. M., \& Hides, M. T. (2000). Developing management systems towards integrated manufacturing: a case study perspective. Integrated Manufacturing Systems, 11(7), 454-461.

Bennis, W., \& Mische, M. (1995). The 21st century organization: reinventing through reengineering. San Francisco: Jossey-Bass Inc. Pub.

Bicheno, J., \& Holweg, M. (2009). The Lean Toolbox: The Essential Guide to Lean Transformation, (4th ed.). Buckingham: PICSIE Books.

Chapman, C. D. (2005). Clean house with lean 5S. Quality progress, 38(6), 27-32.

Cole, R. E. (1994). Reengineering the corporation: a review essay. Quality Management Journal, 1(4), $77-85$.

Davenport, T. H., \& Stoddard, D. B. (1994). Reengineering: business change of mythic proportions? MIS Quarterly, 18(2), 121-127.

Dixon, J. R., Arnold, P., Heineke, J., Kim, J. S., \& Mulligan, P. (1994). Business process reengineering: improving in new strategic directions. California Management Review, 36(4), 93-108.

Doomun, R., \& Jungum, N. (2008). Business process modelling, simulation and reengineering: call centres. Business Process Management Journal, 14(6), 838-848.

Earl, M. J., Sampler, J. L., \& Short, J. E. (1995). Strategies for business process reengineering: evidence from field studies. Journal of Management Information Systems, 12(1), 31-56.

Gadd, K. W., \& Oakland, J. S. (1995). Discontinuous change in a total quality environment. D2D Ltd: A case study. Business Process Reengineering and Management Journal, 1(2), 7-27.

Gapp, R., Fisher, R., \& Kobayashi, K. (2008). Implementing $5 \mathrm{~S}$ within a Japanese context: an integrated management system. Management Decision, 46(4), 565-579.

Grover, V., Jeong, S. R., Kettinger, W. J., \& Teng, J. T. (1995). The implementation of business process reengineering. Journal of Management Information Systems, 12(1), 109-144. 
Hall, G., Rosenthal, J., \& Wade, J. (1993). How to make reengineering really work. Harvard Business Review, 71(6), 119-131.

Hammer, M. (1990). Reengineering work: Don't automate, Obliterate. Harvard business review, 68(4), 104-112.

Hammer, M. (1995). The Reengineering Revolution. HarperCollins Publishers.

Harrington, H. J. (1998). Performance improvement: the rise and fall of reengineering. The TQM Magazine, 10(2), 69-71.

Harrington, H.J. (2000). Business Process Improvement: The Breakthrough Strategy for Total Quality, Productivity, and Competitiveness. New York: McGraw-Hill Inc.

Ho, S. K. (1999). Change for the better via ISO 9000 and TQM. Management decision, 37(4), 381-388.

Johansson, H. J. (1993). Business process reengineering: Breakpoint strategies for market dominance. John Wiley \& Sons.

Karlsson, C., \& Åhlström, P. (1996). Assessing changes towards lean production. International Journal of Operations \& Production Management, 16(2), 2441.

Kelada, J. N. (1994). Is reengineering replacing total quality? Quality Progress, 27(12), 79.-83.

Klarin, M. M., Cvijanović, J. M., Lazić, J. M., \& Spasojević-Brkić, V. (2003). Istraživanje raspoloživosti proizvodnih kapaciteta $\mathrm{u}$ metalopreradi. Industrija, 31(3-4), 1-6.

Klein, M. M. (1993). IEs fill facilitator role in benchmarking operations to improve performance. Industrial Engineering, 25(9), 40-42.
McAdam, R. (2003). Radical change: a conceptual model for research agendas. Leadership \& Organization Development Journal, 24(4), 226-235.

McLay, A. (2014). Re-reengineering the dream: agility as competitive adaptability. International Journal of Agile Systems and Management, 7(2), 101-115.

Michalska, J., \& Szewieczek, D. (2007). The 5S methodology as a tool for improving the organization. Journal of Achievements in Materials and Manufacturing Engineering, 24(2), 211-214.

Oakland, J. (1993). Total Quality Management, (2nd ed.). London: Heinemann.

Osada, T. (1993). The 5S's: five keys to a total quality environment. Japan: Asian Productivity Organization.

Peterson, J., \& Smith, R. (2001). The 5S Pocket Guide. New York: Quality Resources.

Smith, K. K. (1982). Philosophical problems in thinking about organizational change. Change in organizations, 316, 374.

Verespej, M. (1995). Reengineering isn't going away. Industry Week, 244(4): 42-44.

Veža, I., Gjeldum, N., \& Celent, L. (2011). Lean manufacturing implementation problems in beverage production systems. International Journal of Industrial Engineering and Management (IJIEM), 2(1), 21-26.

Vorkapić, M., Popović, B., Ćoćkalo, D., Đorđević, D., \& Minić, S. G. (2015). A Model for Introducing Strategies in Sustainable Development of SmallScale Enterprises in Serbia. Journal of Engineering Management and Competitiveness (JEMC), 5(2), 7783.

\section{PRIMENA 5S ALATA KAO POLAZNE OSNOVE U REINŽENJERINGU POSLOVNIH PROCESA}

U ovom radu analizirani su elementi koji bi predstavljali polaznu osnovu za u primeni reinženjeringa poslovnih procesa. Kao polazna osnova upotrebljen je Lean alat kroz analizu $5 \mathrm{~S}$ modela. Na primeru finalizacije izrade gotovog transmitera u proizvodnji IHMT-CMT-a ustavonljeni su i primenjeni $5 \mathrm{~S}$ alati, ali sa zadrškom na elemente kvaliteta iako teorija ukazuje za su BPR i TQM dve suprotne aktivnosti u preduzeću. Suština rada je samodisciplina zaposlenih na radnom mestu, koja pomaže da se proces finalizacije proizvoda odvija pravovrmeno, bez otpada $i$ gubitaka i da zaposleni stalno održavaju radno mesto uredno, čisto i funkcionalno.

Ključne reči: Reinženjering, TQM, Lean koncept, 5S, Unapređenje proizvodnje. 